\title{
Child Creativity in the Context of Education at Standard and Alternative Schools in Slovakia
}

\author{
Eva Szobiová
}

\begin{abstract}
The contribution gives a review of the research findings mapping (survey) the pupils' creativity level. It provides information about education in alternative schools: Montessori, Waldorf and the Integrated Thematic Instruction (ITI), where the research was realised. The Torrance test (TTCT) and Urban test (TSD-Z) were used for the identification of pupils' creativity. The procreative tendency of the teachers was examined by the Self-Rating Scale of the Creatively Oriented Personality (SRSCP). The comparison of pupils' and teachers' results from standard and alternative schools brought diverse results. Our findings regarding the creativity level of pupils attending the second grade of Montessori and Waldorf schools $(\mathrm{N}=50)$ in comparison with the children in standard schools suggest no significant differences. The pupils of the alternative classes of ITI $(\mathrm{N}=206)$ achieved significantly higher scores of originality than those of standard schools $(\mathrm{N}=194)$. A link between the teachers' creative orientation and their pupils' creativity has not been found.
\end{abstract}

Key words: standard schools, alternative schools, creative thinking, pupil, teacher, creative personality.

\section{Introduction}

Aim of the research: The research was focused on monitoring the creativity level of pupils attending standard and alternative (Montessori, Waldorf and the Integrated Thematic Instruction - ITI) schools in Slovakia. We pressumed that pupils as well as teachers at alternative schools would show higher creativity levels since their pedagogical-educational aims are directed towards creativity as the key characteristic feature of complex personality development. The purpose was to compare the levels of creativity abilities and creativity tendencies of pupils at standard and alternative schools (classes).

Standard (traditional) schools: mostly memory-reproductive with an authoritative role of a teacher; the usage of coersion methods, there is a relatively stable organization of school classes, teaching, and school year; with fixed curriculum and teaching plans defined by „,someone from the outside“-

\footnotetext{
"Eva Szobiová, Faculty of Psychology, Pan-European University, Bratislava, Slovakia; eva.szobiova@paneurouni.com
} 
mainly by the Ministry of Education, with a directive approach to school management and the educational process.

Alternative schools: approaches offering options to traditional institutionalized education or movements which refuse the concept of formal education (according to UNESCO).

Montessori schools: supporting authonomy, creativity, responsibility for own actions; an environment offering mutual respect, cooperation, and help; teachers are highly qualified, show empathy and provide individualized stimuli for all children.

Waldorf schools: encouragement of own opinion, authonomy; emphasis on creativity and own creation of pupils; teachers are "free" creators of curriculum, i.e. "teachers of Waldorf schools are not limited to the curriculum of traditional type and they plan education in cooperation with pupils and partially with their parents as well." (Průcha, 1996, p. 24)

The Integrated Thematic Instruction - ITI: a newer view on the development of psychical functions and processes (Bloom, Gardner), creating a brain compatible environment; innovation of teaching methods and strategies formed on the basis of the discovery principle; revisions of curriculum and creating a year-long theme to organize the curriculum content.

Sample: Pupils attending 2nd grades at Montessori and Waldorf school $(\mathrm{N}=50)$ versus pupils at standard school $(\mathrm{N}=35)$ in Bratislava (average age 8 years; $\mathrm{SD}=$ 4.79 month). Pupils in 3rd and 4th grades (9 - 10 years) of 10 alternative classes following the Integrated Thematic Instruction model $(\mathrm{N}=206)$ versus pupils in 3rd and 4th grades of 9 classes at standard schools $(\mathrm{N}=194)$ in Bratislava, Banská Bystrica and Pezinok.

\section{Methodology and research methods}

The Torrance test of Creative Thinking (TTCT) - Incomplete Figures (Jurčová, 1984); The Urban figural test of creative thinking - TSD - Z (Urban, Jellen and Kováč, 2002); PACT - Pennsylvania Assessment Creative Tendency (Rookey, 1971); Self-rating Scale of the Creatively Oriented Personality - SRSCP, (Szobiová and Fichnová, 2003).

For the purposes of creativity identification, a second subtest, The Incomplete Figures, was used from Torrance Figural Test of Creative Thinking, standardized for Slovakia by M. Jurčová (1984). It is a well-known and verified testing method in which ten incomplete figures are to be used as a basis for drawing interesting objects or pictures that would not be made up by anyone else. For each of the pictures then a story has to be devised, the most complex and interesting possible, with an ingenious and unusual title. In the test measuring the individual's tendency to structuration and integration, three indicators of creativity were assessed: 
- fluency - the number of relevant (adequate) answers

- flexibility - the number of various solutions indicating different tendencies in solving tasks, a change in the approach, the ability to change the way of thinking

- originality - the score is determined by low statistical frequency, the measure representing the decline from what is current, ordinary or evident.

The fluency score was represented by the number of acceptable answers. The flexibility points were gained by the creations belonging to various categories (however, they are not of the same degree of universality and they depend on the frequency of occurrence of the given theme). Originality was measured by a $0-3$ point scale, on the basis of the frequency of occurrence of individual themes in the investigated sample. 0 points were gained by the answers occurring in more than $5 \%$ of the cases, 3 points were gained by fanciful, uncommon answers, occurring in less than $1 \%$ of the cases.

The TSD-Z (Urban Creative Thinking Test, the Slovak form adapted by Urban, Jellen and Kováč, 2002) is based on the principle of uncompleted figures or shapes. There are five figures enclosed in a frame and the last one, the sixth one, is outside the frame. The proband's task is to complete the drawing by individual shapes. This test also reflects the personality dimensions of creativity, such as taking risks, overcoming obstacles, complexity of the view, etc. Urban and Jellen, the authors of the test, are of the opinion that in comparison with the Torrance tests the Urban test is more objective in reflecting the age differences in creative performances.

Using the PACT questionnaire (Pennsylvania Assessment Creative Tendency, Rookey, 1971), we examined the levels of creative tendency among schoolchildren. This questionnaire includes 19 statements (i.e. I like to try new things). The proband's task is to express his/her agreement or disagreement on a 5 -point Likert scale $(5$ - absolute agree -4 moderate agree -3 uncertainty -2 moderate disagree -1 absolute disagree). The reliability and validity of the questionnaire were verified throughout several research projects in the USA. According to the author's opinion (Rookey, 1971), this method offers valid assessment of creativity in pupils, because it eliminates stress from tasks and the form of statements does not distort the results.

SRSCP (Self-rating Scale of the Creatively Oriented Personality, authors Szobiová and Fichnová, 2003) is a relatively exact questionnaire method of prompt orientation, serving the purposes of identification of procreatively oriented personality types of school teachers on the basis of self-rating of their own preferred ways of behaviour and experience in the described situations of both personal and professional character. Procreative orientation - this term describes the type of personality with which it is possible to identify a certain tendency to creativity as such openness to new trends, as well as certain procedures and approaches to the work and further characteristics or traits shared 
by creative individuals, however, it does not mean that these abilities are invariably manifested in each procreatively oriented personality. Personalities of this kind actively co-operate in introducing new forms, procedures, etc., they show interest in the growth of both their own creative abilities and those of the children in their care. Verification of the SRSCP (Szobiová and Fichnová, 2003) with a sample of $\mathrm{N}=111$ has shown its high internal consistency, as well as its highly significant correlations with classical creativity measures - TTCT Torrance (Jurčová, 1984).

Statistic procedures: ANOVA - analysis of variance, Mann-Whitney test, Kruskal-Wallis test, t-test, non-parametric correlations.

\section{Results}

Table 1 Comparison of attained scores of creativity factors of pupils attending standard ( $\mathrm{s}$ ) and alternative ( $\mathrm{a}=$ Montessori, Waldorf) primary schools

\begin{tabular}{|c|c|c|c|c|c|c|c|c|c|c|}
\hline & FLs & FLa & FXs & FXa & ORIGs & ORIGa & ELABs & ELABa & SUMAs & SUMAa \\
\hline $\mathbf{N}$ & 35 & 50 & 35 & 50 & 35 & 50 & 35 & 50 & 35 & 50 \\
\hline AM & $\mathbf{9 . 9 6}$ & $\mathbf{9 . 3 6}$ & 5.50 & 4.91 & 15.46 & 13.45 & $\mathbf{9 . 5 7}$ & $\mathbf{3 . 9 5}$ & $\mathbf{4 0 . 5 0}$ & $\mathbf{3 1 . 6 8}$ \\
\hline SD & 0.19 & 1.76 & 1.00 & 1.15 & 3.54 & 4.68 & 9.19 & 3.91 & 8.75 & 7.78 \\
\hline Minimum & 9.00 & 2.00 & 4.00 & 1.00 & 10.00 & 4.00 & 0.00 & 0.00 & 28.00 & 7.00 \\
\hline Maximum & 10.00 & 10.00 & 8.00 & 6.00 & 27.00 & 23.00 & 33.00 & 13.00 & 61.00 & 44.00 \\
\hline
\end{tabular}

\section{Explanatory notes:}

FLs, FXs, ORIGs, ELABs, SUMAs = values of fluency, flexibility, originality, laboration factors and the total score obtained from pupils at standard primary schools.

FLa, FXa, ORIGa, ELABa, SUMAa = values of fluency, flexibility, originality, laboration factors and the total score obtained from pupils at alternative primary schools. 


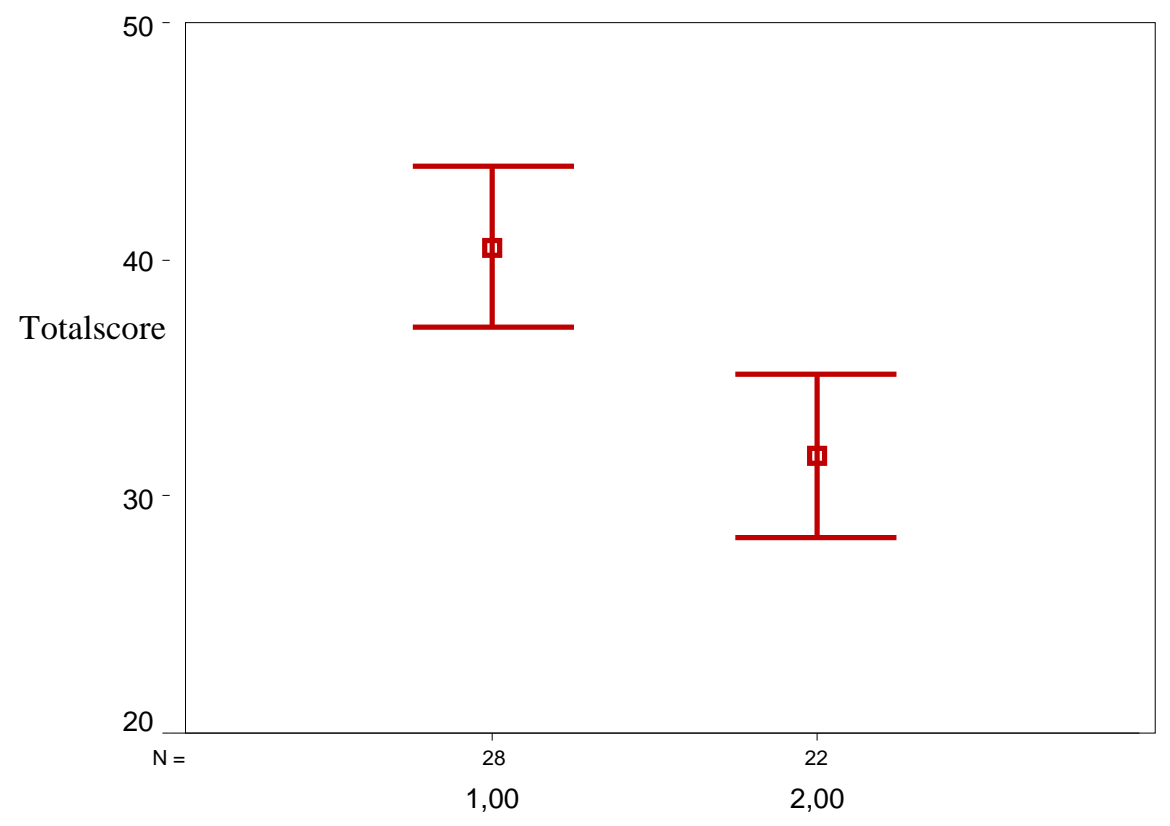

School

Notes: $1=$ standard primary school, $2=$ alternative primary school

Figure 1 Comparison of the attained results in total scores of pupils attending standard and alternative (Montessori, Waldorf) primary schools. The line represents $95 \%$ of results.

Table 2 Statistical significance of differences in each factor of creativity and the total score of pupils attending standard or alternative (Montessori, Waldorf) primary schools

\begin{tabular}{|l|l|l|l|l|l|}
\hline & FL & FX & ORIG & ELAB & SUMA \\
\hline $\mathbf{P}$ & $0.036^{*}$ & 0.167 & 0.152 & $0.028^{*}$ & $0.001^{* *}$ \\
\hline
\end{tabular}

FL: APA $(\mathrm{U}=247.500 ; \mathrm{p}=0.036)$

FX: APA $(\mathrm{U}=243.000 ; \mathrm{p}=0.167)$

ORIG: APA $(\mathrm{U}=235.000 ; \mathrm{p}=0.152)$

ELAB: APA $(U=196.000 ; p=0.028)$

SUMA: APA $(\mathrm{U}=139.500 ; \mathrm{p}=0.001)$

\section{Explanatory notes:}

$*=5$ per cent level of significance, $* *=1$ per centlevel of significance, 
FL, FX, ORIG, ELAB, SUMA = fluency, flexibility, originality, elaboration, the total score

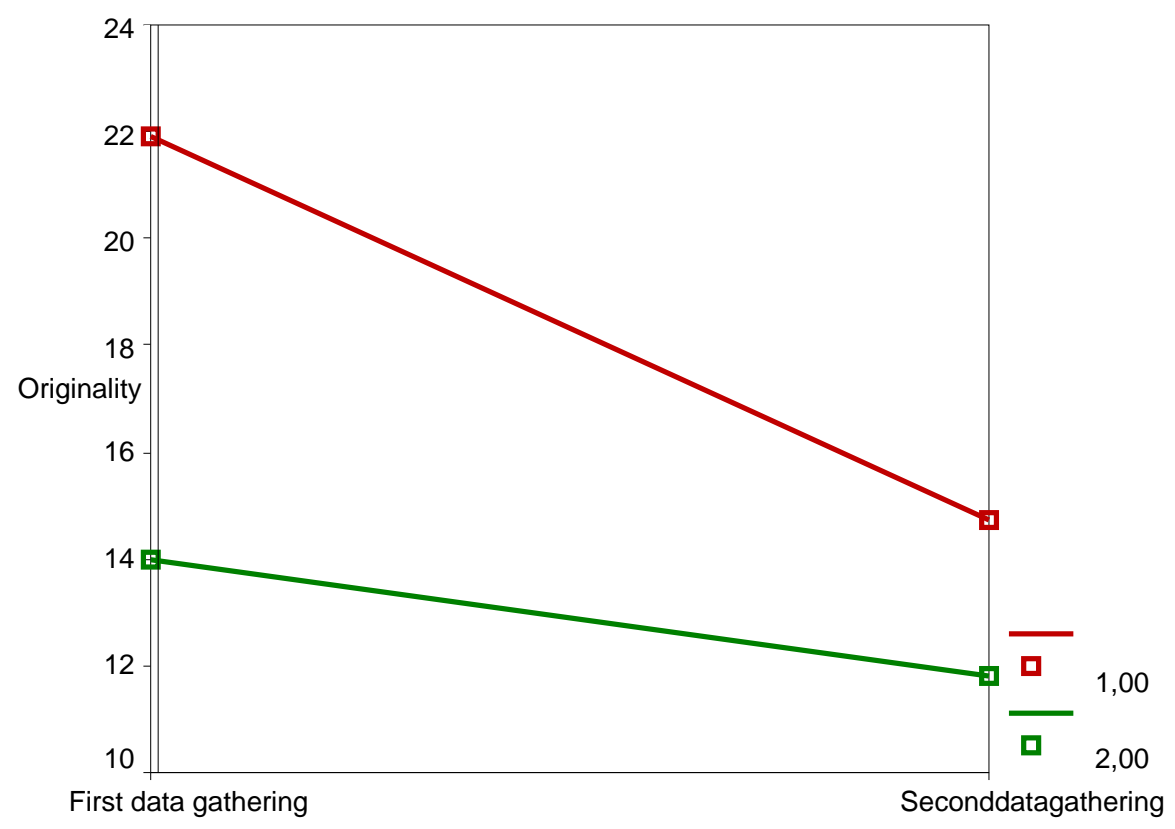

Testing

Figure 2 Illustration of differences over time (after 2 years) in the level of creativity factor in pupils attending standard or alternative (Montessori, Waldorf) schools

Table 3 Correlations between scores of standard school teachers and alternative school teachers $(\mathrm{N}=11)$ in the SRSCP and length of their service and creativity level in pupils

\begin{tabular}{|l|l|l|l|l|}
\hline & FL & FX & ORIG & SUMA \\
\hline SRSCP & $1.000^{* *}$ & 0.000 & 0.800 & 0.800 \\
\hline SRSCP1 & 0.800 & 0.600 & 0.400 & 0.400 \\
\hline${ }^{\circ}$ Practice & $1.000^{* *}$ & 0.000 & 0.800 & 0800 \\
\hline
\end{tabular}

\section{Explanatory notes:}

FL, FX, ORIG, SUMA = fluency, flexibility, originality, the total score 
Table 4 Comparison of the attained scores of creativity factors in the TTCT and the Urban test of pupils attending standard $(\mathrm{s})$ and alternative $(\mathrm{a}=\mathrm{ITI})$ primary schools

\begin{tabular}{|c|c|c|c|c|c|c|c|c|c|c|}
\hline & FLs & FLa & FXs & FXa & ORIGs & ORIGa & TSD-Zs & TSD-Za & PACTS & PACTa \\
\hline $\mathbf{N}$ & 194 & 206 & 194 & 206 & 194 & 206 & 194 & 206 & 194 & 206 \\
\hline $\mathbf{A M}$ & 9.86 & 9.76 & 7.31 & 7.63 & 16.29 & 20.67 & 33.20 & 34.83 & 50.40 & 47.65 \\
\hline SD & 0.85 & 0.44 & 1.30 & 1.02 & 4.07 & 4.56 & 10.23 & 9.66 & 6.67 & 8.54 \\
\hline $\begin{array}{c}\text { Mann- } \\
\text { Whitney } \\
\text { U }\end{array}$ & & 238.00 & $\begin{array}{r}\mathrm{Kru} \\
\mathrm{Wa} \\
\mathrm{X}^{2}=\end{array}$ & & \multicolumn{2}{|c|}{$t=5.06$} & \multicolumn{2}{|c|}{ ANOVA } & \multicolumn{2}{|c|}{$\begin{array}{l}\text { Kruskal Wallis } \\
\qquad X^{2}=4.111\end{array}$} \\
\hline $\begin{array}{c}\text { Wilcoxon } \\
\text { W }\end{array}$ & $\begin{array}{r}291.00 \\
\mathrm{Z}\end{array}$ & $=1.271$ & $\mathrm{Si}$ & & $\mathbf{p}<$ & 0.01 & \multicolumn{2}{|c|}{ Sign. } & \multicolumn{2}{|c|}{$\begin{array}{l}\text { Sign. } \\
.128\end{array}$} \\
\hline
\end{tabular}

Table 5 Scores of creativity tendency of the PACT questionnaire in teachers of standard and alternative classes with the Integrated Thematic Instruction

\begin{tabular}{|l|l|c|c|}
\hline Teachers & \multicolumn{2}{|l|}{ Scores of creativity tendency } & T - value \\
\hline $\begin{array}{l}\text { Alternative } \\
\text { classes }(\mathbf{N}=\mathbf{1 0})\end{array}$ & $\mathrm{AM}=79.43$ & $\mathrm{SD}=10.73$ & \\
\hline $\begin{array}{l}\text { Standard } \\
\text { classes } \\
(\mathbf{N}=9)\end{array}$ & $\mathrm{AM}=74.20$ & $\mathrm{SD}=9.84$ & 1.77 \\
\hline
\end{tabular}

\section{Discussion and conclusions}

Contrary to our pressumptions we found out that the pupils attending standard primary schools achieved significantly higher scores in the factors of fluency, elaboration and in the total score in comparison with pupils attending alternative (Montessori, Waldorf) primary schools.

The level of originality factor of the pupils attending standard education has significantly decreased two years after primary school entry. On the other hand, the originality of pupils attending alternative schools (Montessori, Waldorf) has declined only non-significantly over the same time. We can conclude that alternative schools in our sample had a more favourable effect on creativity 
development than the standard schools, the impact of which was obviously more negative.

The pressumption regarding a positive relationship between the procreative orientation of teachers and the creativity level of their pupils was confirmed only in the fluency factor. We noted positive correlations between the creative orientation of teachers and the length of their service.

The pupils of alternative classes with the Integrated Thematic Instruction (ITI) show significantly higher figurative originality level in comparison with the pupils of standard schools. This type of education probably affects progress of pupils in graphic creativity more intensively.

The teachers of alternative classes express a stronger tendency for creativity. We assume that more flexible teachers are more likely to be engaged in alternative schools with the ITI.

\section{References}

GALLOVÁ, S. Vývin detskej tvorivosti pôsobením štandardnej a alternatívnej edukácie (Master's thesis). Bratislava: Filozofická fakulta, Univerzita Komenského, 2010.

JURČOVÁ, M. Torranceho figurálny test tvorivého myslenia, forma B.: Príručka: Praktická čast'. Bratislava: Psychodiagnostické a didaktické testy, 1984.

ROOKEY, T. J. Pennsylvania Assessment of Creative Tendency. Norms Technical Manual. Pennsylvania: Department of Education, 1971.

REINPRECHTOVÁ, R. Edukácia valternatívnych školách a jej vplyv na tvorivost' žiakov (Bachelor's thesis). Bratislava: Filozofická fakulta, Univerzita Komenského.

SALBOT, V. and SABOLOVÁ, G. Tvorivost' a jej rozvíjanie v škole. Banská Bystrica: Pedagogická fakulta, Univerzita Mateja Bela, 1998.

SZOBIOVÁ, E. and FICHNOVÁ, K. Self-Rating Scale of Procreatively Oriented Personality (SRSCP) adapted for Kindergarten Teachers in relation to creative achievements. Studia Psychologica, 45, 2003, 4, 307-321.

URBAN, K. K., JELLEN, G. H. and KOVÁČ, T. Urbanov figurálny test tvorivého myslenia (TSD-Z): Príručka. Bratislava: Psychodiagnostika, a.s., 2002. ZELINA, M. Alternativne školstvo. Bratislava, IRIS, 2000. 